\title{
Neo-liberalism at a Time of Crisis: the Case of Taxation*
}

\author{
DRIES LESAGE and MATTIAS VERMEIREN \\ Ghent Institute for International Studies, Universiteit Gent, Belgium. E-mail: \\ dries.lesage@ugent.be; matthias.vermeiren@ugent.be
}

This essay explores how the global financial crisis of 2008-2009 has affected the stability of what Stephen Gill has termed the 'new constitutionalism of disciplinary neo-liberalism', ${ }^{1}$ more precisely, in the realm of international tax policy. Rather than providing an in-depth and complete empirical study of the matter, this essay will highlight certain interesting developments and touch upon a series of possibly relevant questions that could form the basis for a future research agenda. In the first section, we will examine the remarkable strength and resilience of the new constitutionalism as the institutional component of neo-liberal hegemony. Then we will proceed to an exploration of the impact of the crisis on this hegemony, also paying attention to deepening geopolitical multipolarity as an additional variable. The final, more empirical section will investigate the case of international taxation in this context, and demonstrate that new constitutionalism remains a crucial supporting pillar of neo-liberal globalisation.

\section{New constitutionalism of disciplinary neo-liberalism as a 'Gestalt of scales'}

Stephen Gill defines new constitutionalism of disciplinary neo-liberalism as the political project aimed at anchoring neo-liberal policies of privatisation, liberalisation and pro-market regulation, as well as monetarist objectives, into national and international legal frameworks, insulating these policies from normal, day-to-day democratic debate and decision-making. Analogous to national constitutions, these frameworks can only be modified in extraordinary political circumstances and through burdensome procedures, often requiring special majorities or unanimity. At the national level, one can think of legal provisions

\footnotetext{
*The text was finalized in December 2009.
} 
concerning the political independence of the central bank. Examples of new constitutional arrangements at the international level are the regime of the World Trade Organisation (WTO); the Western-biased and relatively undemocratic governance structures of the International Monetary Fund (IMF) and World Bank, which make it easier for these institutions to apply neo-liberal conditionality; the Code of Liberalisation of Capital Movements of the Organisation for Economic Cooperation and Development (OECD); the European internal market and economic and monetary union, where very concrete neo-liberal norms are anchored in the treaty; the statutes of the European Central Bank (ECB); and the plethora of regional and bilateral free trade agreements, which often include provisions that go beyond the WTO acquis in a neo-liberal sense. As such, new constitutionalism legally encodes the regulatory dimension of neoliberal globalisation, in particular with regard to free movement of products and production factors and property rights (Ref. 1, pp. 138-142).

Having said that, it is useful to see the concept of new constitutionalism, being the legal anchoring of neo-liberal globalisation, in relation to the latter's economic anchoring. Both are narrowly intertwined. For individual states and even groups of states it has become extremely difficult to withdraw from certain international legal arrangements, because the underlying economic interconnectivity between countries is no longer escapable. For their long-term prosperity, states need, for example, the presence of transnational corporations on their soils, since the latter possess unique assets (capital, technology, know-how, access to valuable networks for sourcing and distribution, marketing information, and so on), to which purely national firms in many cases no longer have access. In their turn, transnational corporations want host states to conduct policies that promote globalisation. Investment regimes should be open, with little regulation that could hamper the companies' free operation and decision-making. By the same token, transnational corporations insist on at-the-border trade openness for their intermediary products and exports, as well as financial openness (i.e., no capital controls or financial transaction taxes) for their lending, investment, profit shifting, hedging and other financial operations. In this context, officially embracing new constitutionalism is a signal to the markets that the country is willing to provide an attractive investment climate on a permanent basis. Financial and economic at-the-border openness, and being a member to certain international pro-market frameworks, have become competitive assets in their own right, in addition to domestic neo-liberal policies (such as lower taxes and flexible labour markets), generating a transition of the era of the (Keynesian) welfare state to that of the competition state. ${ }^{2}$ What is more, neo-liberal constitutionalist frameworks are a part of a wider set of international regimes that help states to manage globalisation as a 'thicker' form of complex interdependence. Defecting from neo-liberal frameworks could cause unpredictability, retaliation and reputation damage in other regimes. ${ }^{3,4}$ In the same vein, new 
constitutionalism strongly discourages temporary and sectoral amendments or opt-outs by rendering them 'illegal', even in cases where governments in the absence of a legal framework would deem the benefits of such a derogation larger than the costs. It also prevents groups of states from gradually eroding the overall framework of neo-liberal globalisation in a more collective way.

It is equally interesting to appreciate the political-geographical dimension of new constitutionalism. It legally anchors the free movement of capital, goods and services as one of the main drivers of neo-liberal globalisation, in order to secure a relatively open international market space. In the meantime, however, policies of market correction (social, environmental, taxation) most of the time still reside at the national level. In this way, new constitutionalism more or less freezes a politicalgeographical mismatch between market promotion and market correction, or - as political geographers studying 'politics of scale' would put it - codifies a certain 'Gestalt of scales', a specific configuration of different political scales at which respective economic, social and political activities are located. In this case, investment and trade enjoy a huge (potential of) mobility on a vast scale (e.g., EU-wide, global), enabling transnational corporations to play off one against another politicalregulatory jurisdictions at lower scales by engaging in 'regime shopping' or 'regulatory arbitrage'. This phenomenon demonstrates that organisation of human activity at certain political-geographical scales is far from a power-neutral process.

This unique new constitutionalist Gestalt of scales forms the institutional component of neo-liberal hegemony. Lending some concepts from neo-Gramscian International Political Economy, one can understand neo-liberal globalisation as the product of a 'hegemonic bloc' directed by a transnational capitalist class (international finance and transnational corporations) and undergirded by material, ideational and institutional components. In the material realm, we see the predominance of transnational capital, assisted by the governments of the advanced industrialised and emerging countries, as well as by their potential mobility and concomitant 'exit option', which disciplines governments, parliaments and national trade unions. In this respect, new constitutionalism and its focus on financial and trade openness have increased the structural power of transnational capital, inducing national governments to embrace neo-liberal-oriented policy regimes in order to thwart off potential investment strikes and/or capital flight. ${ }^{6}$ In the ideational sphere, militant neo-liberalism has been succeeded by the seemingly more politically 'neutral' globalisation discourse, which pretends that states have lost a considerable deal of their actual sovereignty and that for nations there is no alternative to adjusting to the exigencies of internationally mobile investors. It is through the globalisation discourse that neo-liberalism has succeeded in colonising Christian- and socialdemocracy as well, of which Tony Blair's 'Third Way' and Gerhard Schröder's 'Neue Mitte' are well-known articulations. This compact of material forces and ideas is supported by a plethora of institutional mechanisms at the national and 
international scale, ranging from bilateral trade and investment agreements over global arrangements, such as the multilateral trade regime, to powerful and influential institutions, such as the G7, WTO and IMF, which advocate, design, push and police neo-liberal globalisation policies, while keeping market-corrective regulation at lower levels. In this way, the three components that make up the hegemonic bloc a ruling class with a certain world view and specific relations with other groups - are mutually reinforcing. In particular, the new constitutionalist institutional architecture, itself the product of transnational capitalist interests and neo-liberal ideas, that had broken through in the $1980 \mathrm{~s}$, both serves certain material interests and feeds a disempowering globalisation discourse as the more 'neutral' accomplice of neo-liberal ideology.

\section{The impact of the crisis}

One could argue that the neo-liberal hegemony can only be undone by fundamental changes in one or more of the three supporting pillars. Provided that an institutional constellation is, to a large extent, the product of material and ideational forces, one has to wait for changes in the latter two in order to get overall transformation of the hegemonic bloc or its replacement. The problem now is that new constitutionalism as the institutional pillar of neo-liberal hegemony has adopted a life on its own, contributing to the stability and resilience of the process of neo-liberal globalisation in an exceptional way. Legal and economic anchoring makes it for individual states almost impossible to de-link from neoliberal globalisation, even when transformations in domestic social relations and hegemonic ideology tend in that direction. Only great powers, or blocs like the European Union (provided that it can find internal consensus), might consider such a move, boasting, among other things, upon their market power. But even for them, re-introducing huge trade barriers or strict capital controls could provoke particularly harmful reactions from the markets. In some instances, however, the disciplining globalisation discourse and its focus on international competitiveness are instrumental in exaggerating the confines of the 'politically possible', thus overlooking opportunities for change. ${ }^{7,8} \mathrm{~A}$ case in point are the technical possibilities to successfully implement a Tobin tax at the national or Euro-zone level, even without the participation of other major financial centres. ${ }^{9}$

All this means that neo-liberal globalisation can persist for a very long time, even if in several parts of the world dominant material and ideational forces have already rejected neo-liberalism, so that the latter is no longer 'hegemonic' in the Gramscian sense (i.e. based on consent) but has grown 'coercive'. In these cases 'supremacy' has replaced 'hegemony' (Ref. 1, pp. 142-149). It follows that fundamental change towards a different order can only be brought about by a broad, intercontinental shift in the material (i.e. social forces gaining power over 
others) and/or ideational sphere. A severe global crisis is typically a kind of event that can undermine the ideational pillar of a certain hegemony, by empowering oppositional groups and detaching certain social groups from the ruling ones. After all, these were the conditions under which neo-liberalism could take over in the wake of the economic crisis of the 1970s. Now the question is whether the 2008-2009 global financial meltdown could have a similar effect.

Without any doubt, the crisis has delivered a blow to the legitimacy of neo-liberal ideas. Yet, this does not imply that the whole neo-liberal legacy will be swept away altogether. The criticism mostly targets the insufficient regulation and supervision of the financial sector (including offshore financial centres or tax havens) and the 'greed' many players in that sector have allegedly displayed. Accordingly, the financial reform agenda is mainly focused on technical regulatory issues such as capital adequacy measures and accounting rules, while bringing hedge funds, bonuses, and tax havens into the scope of (non-stringent) global regulation. As such, the reform agenda 'did not go much beyond the pre-existing international initiatives that had recently been developed in more technocratic international bodies' (Ref. 10, p. 275). Consequently, key characteristics of neo-liberal globalisation - free trade and capital mobility - stay out of the current controversy. It is true that the Doha round of the WTO is stuck in the morass, but this was already the case before the crisis. Importantly, the crisis has not engendered calls to roll back the existing neoliberal attainments of the WTO. To the contrary, the leaders' summit of the G20 has spoken out in favour of a successful completion of the Doha Round. ${ }^{11}$ Even more striking is the fact that the crisis has hardly sparked any debate about financial globalisation as such and the free movement of capital. ${ }^{12}$ In the perception of the elites and the public, the causes of the crisis are largely situated at the domestic level (in the US and elsewhere), while (neo-liberal) globalisation as such is not to blame.

In the material realm, some particular interests have incurred damage. Governments, somewhat more than before, acting on behalf of other social groups (including the ordinary tax payers), seem to have regained the self-confidence to keep the bankers in check. As Thirkell-White has pointed out, public anger over the credit crisis and large-scale protests have increased the politicisation of the global financial reform process to a considerable degree, 'triggering the rise of a populist politics seeking punishment for the banking sector' (Ref. 13, p. 689). Politicians are searching for measures that will force the financial sector (and possibly the speculators) to pay, for instance by curbing and/or taxing excessive remuneration of cadres and traders. But at the same time, capitalist and labour interests of the financial sector in New York, London and other financial centres still exert strong influence over the policies of their respective governments. Even more importantly, transnational corporations - vehement defenders of an open economic and financial world order - are still at the core of today's global productive system and will not easily support fundamental deviation from neo-liberal globalisation. 
Given the limited anti-liberal critique at the ideational level, no powerful global movement has emerged urging for a fundamental transformation of the institutional component of neo-liberal hegemony. Free trade and free movement of capital remain the norm, and the current levels of international liberalisation are not turned back fundamentally. In this way, globalisation can continue to discipline national governments, and so can new constitutionalism to disempower counter-hegemonic social forces and ideas. There is another feature of the institutional component of neo-liberal hegemony that now proves functional in sustaining the hegemony: the relative insulation of the financial regulatory establishment from the rest of politics and society. While at the domestic level the crisis has increased the politicisation of financial policy-making, at the international level the financial reform process continues to be governed by a transnational network of finance ministries, central banks and a plethora of highly technocratic financial regulatory bodies. Actors within this transnational policy community traditionally hold on to a neo-liberal policy paradigm, while their conservative world views are reinforced by the highly technical nature of their expertise - impeding participation from other stake-holders - and the active involvement of the private sector in the global financial governance process. Although the financial private and public establishment is now under fire, it still monopolises almost all relevant expertise, and is needed to design and implement solutions. Therefore, bringing other social interests to the table of financial decision-making is key to counter-hegemonic action. ${ }^{14-16}$

Let us conclude this section with a reflection on the deepening of multipolarity in relation to the issue at hand. The emergence of China, India, Brazil, Russia (i.e., the so-called BRICs) and other newly industrialising countries could have brought different material interests at the centre of international financial and economic decision-making. However, there are plenty of indications that the counter-hegemonic potential of these countries should not be overstated. These countries also possess a mix of offensive, internationalist and rather defensive, protectionist capitalist interests, just like the West, with governments more often than not promoting the former. Since 2001 China is a committed member of the WTO, which has also caused severe economic shocks and restructuring to the detriment of defensive interests in China itself. ${ }^{17}$ The IBSA countries (India, Brazil, South Africa) have increasingly subscribed to the norms of neo-liberal globalisation. ${ }^{18}$ Part of their stubbornness in the current Doha Round of the WTO through the G20 of southern powers, which are mostly agricultural exporters relates to their tough demands on agricultural liberalisation in the North as a precondition to discuss more openness on industrial goods and services in their own countries. The final result of such a bargain could be an intensification of neo-liberal globalisation rather than the opposite. The recent summits of the G20 for financial matters in Washington, London and Pittsburgh (2008-2009) did by no means serve as the sites for a great clash between a neo-liberal West and a counter-hegemonic 
south. Admittedly, the emerging economies insist upon a bigger say in institutions like the UN Security Council, IMF and World Bank, but the adaptation of these institutions (for which momentum is growing), including the launch of the permanent G20 summit, does not imply the end of neo-liberal globalisation. It is true that certain emerging economies, such as China and Russia, still run a more stateinterventionist capitalism at home and operate on world markets through state-led energy companies and sovereign wealth funds. But across the board, they play by the rules and, as far as international regimes for trade, direct investment and capital movement are concerned, do not demand a fundamentally different institutional hardware for the world economy. ${ }^{19}$

\section{International turbulence and tax policy}

As a result of recent international financial and economic turbulence, the perceived lack of international tax cooperation has come prominently in the picture. Independent from the financial crisis, in the course of 2007-2008 big international tax scandals erupted in connection with the Swiss bank UBS and the Liechtenstein-based wealth manager LGT. Both were accused of assisting wealthy citizens from the US, Germany and other countries in hiding taxable income from their respective tax authorities. The financial crisis indirectly added to the growing awareness about ill-conceived tax policies. First, the loosely regulated 'offshore financial centres' or 'tax havens' served as an ideal place to accommodate the structured investment vehicles that were used by international financial institutions to conceal and remove highly complex and risky financial operations and products from their balance-sheets. In this way, tax havens have contributed to the rise of a 'shadow banking system' that was able to disperse trillions of dollars of toxic products all over the world economy. ${ }^{20}$ Second, some governments raised objections about bailing out banks with public money, while some of those banks were still in the business of helping citizens and companies to avoid and evade taxes, including through their own branches in tax havens. ${ }^{21}$ Third, the financial crisis has catapulted the old idea of a tax on financial transactions on top of the global international agenda. In the remainder of this paper we will explore how and to what extent the crisis and the scandals have impacted upon international tax policy, more precisely with regard to issues such as cross-border tax evasion, inter-state tax competition and Tobin-like taxes. We will do so through the lens of ideas, material interests and institutions.

An ideational backlash against socially unfair tax practices in the context of neoliberal globalisation (e.g. the use of tax havens, manipulative profit shifting by multinationals, fierce tax competition between states, lack of information exchange between jurisdictions) is not entirely new in recent times. In the second half of the 1990s, both the European Union (EU) and the Organisation of Economic 
Development and Cooperation (OECD) embarked upon a crackdown against a series of harmful tax practices. This has resulted in the European savings directive (ensuring effective taxation in the EU upon certain financial assets through a system of information exchange and withholding taxes), EU and OECD codes of conduct against special corporate tax schemes, a tougher stance on special tax incentives via the European state aid rules, and an OECD initiative vis-à-vis tax havens worldwide to promote more transparency and information exchange upon request. ${ }^{22}$ The recent tax scandals and the financial crisis have reinvigorated this debate. Western leaders have adopted more militant language on 'letting the bankers pay' and 'closing down tax havens'. In this context, the renewed interest for a variant of the Tobin tax should be noted. The international political support for this idea has reached unprecedented levels, with Gordon Brown, Nicolas Sarkozy and Angela Merkel at the forefront of the campaign. Even key players in the financial sector, such as Lord Turner, chairman of the Financial Services Authority in the UK, and - recently and moderately - Dominique Strauss-Kahn, head of the IMF, have spoken out in favour of the idea. The US government remains very reluctant, however. ${ }^{23-25}$ Ideas for internationally concerted taxes on bankers' bonuses and levies on banks to finance bailout funds, are also on the table of international fora. ${ }^{26,27}$

The current backlash particularly targets the financial sector (banks, offshore financial centres, financial transactions, etc), but the problem of tax competition between countries (notably with regard to corporate taxation) remains largely out of the scope of the international policy debate. It must be said, however, that the new atmosphere has helped to raise awareness on the link between unsocial tax practices and development. The premier site for this debate was the UN follow-up conference on 'Financing for Development' in Doha in Fall 2008. The outcome document of that conference does not contain many palpable references to this issue, but in the run-up a major breakthrough at the ideational level has been realised thanks to the Leading Group on Innovative Financing for Development (an intergovernmental group launched by France and Brazil in 2006), governmental officials from Norway, Germany and South Africa, the secretariats of the UN and OECD, and NGOs such as the Tax Justice Network and Global Financial Integrity, with, in their slipstream, established NGOs such as Oxfam and ActionAid. Through this movement, for the first time in history, a broad globalisation-related and development-relevant tax agenda (e.g. taxation of multinationals and extractive industries, capital flight to tax havens, technical assistance to developing countries on tax, and so on) was brought to the attention of the international community, with ample resonance in the international press. ${ }^{28}$ The following quote from the head of the OECD, Angel Gurría, gives a good idea of the changed mood:

Tax dodgers in developed and developing countries deprive governments of revenues. Many take advantage of the lack of transparency in tax havens. Developing countries are estimated to lose to tax havens almost three times 
what they get from developed countries in aid. If taxes on assets hidden by tax dodgers were collected in their owners' jurisdictions, billions of dollars could become available for financing development. ${ }^{29}$

As far as material interests are concerned, it is obvious that financial capital is on the defensive. By undermining its ideational base, the crisis has seriously harmed its hegemonic status. The events have empowered other social forces and ideas, which are now increasingly reflected in governmental policies. Bankers and other financial institutions will have to pay, and even more so depending on the success of transnational regulatory cooperation - think of a global financial transactions tax. Without any doubt, public regulation of the financial sector will be stepped up. But the fundamental question here is whether, as a direct or indirect result of the crisis, the most wealthy in society as a whole will have to pay more taxes, in particular by curbing their possibilities to use and misuse neo-liberal globalisation.

At the national level, several Western countries are tightening their policies vis-àvis tax havens. The British Crown Dependencies Guernsey, Isle of Man and Jersey, as well as Overseas Territories such as Bermuda and Cayman Islands have come under scrutiny by the UK government against the backdrop of rising international criticism on tax havens, and offshore centres are becoming themselves victims of the crisis. It is even feared that some Caribbean jurisdictions could become failed states. ${ }^{30}$ Following the bailing out of banks, has the time come to bail out tax havens, after they have been facilitating massive tax evasion for decades? An independent review report to the British government now recommends that all tax havens subscribe to OECD standards on information exchange, sign information exchange agreements with the countries they have important financial links with, enter into the EU system of automatic information exchange, and raise their own taxes to save their treasuries. The report also calls upon the UK to take the lead internationally to improve OECD standards on the question of identification of real ownership (see below). ${ }^{31}$ Under pressure from their government, the French banks decided collectively to close their branches and subsidiaries in offshore financial centres that do not meet certain standards on transparency and information exchange. ${ }^{32}$ In the US, the 'Stop Tax Haven Abuse Act' is still pending. ${ }^{33}$ In August 2009, US tax authorities won a legal battle with the Swiss bank UBS forcing the latter to provide thousands of American citizens' account details. This event has further undermined Swiss banking secrecy and sets a very important precedent that will progressively limit the possibilities of offshore tax evasion. ${ }^{34}$ The leakage of account details from the Liechtenstein-based wealth managing institution LGT and the firm reaction by the German and other authorities have also sent a signal to tax dodgers that their activities have become quite dangerous for themselves. Growing awareness in the South on the link between proper tax policies and development, including increasing activity to exchange best practices and expertise among countries, gives hope that in the coming years more tax revenue will be raised. ${ }^{28}$ 
As for international cooperation in curbing tax evasion, the result thus far is less convincing, despite all the talk in the run-up to G20 summits on 'closing down tax havens'. The G20 has endorsed the OECD standards with regard to exchange of information. This standard means that jurisdictions fully cooperate with respect to any foreign demand for information on a particular tax payer, with the exchange prevailing over domestic banking secrecy or any other domestic regulation. To be clear, this is about information exchange upon request, in relation to a certain tax payer, and not automatic information exchange concerning all tax payers, which would be a much more powerful device to deter offshore tax evasion. At its April 2009 London summit, the G20 and OECD published a grey list (jurisdictions that have committed to the standard, but have not yet implemented it) and a black list (jurisdictions that have not committed to the standard). By signing just 12 agreements with other countries on information exchange, a jurisdiction can move from the grey list, which is what several countries have done in the course of 2009. Moreover, at this moment, the G20/OECD black-list is empty, as the four remaining tax havens have committed to the standard shortly after the London summit. This renders the G20 threat to apply sanctions against black-list jurisdictions quite hollow. For example, Liechtenstein (with at the time of writing only 12 bilateral tax information exchange agreements, including with a number of other tax havens) is now on the 'white' list of 'jurisdictions that have substantially implemented the internationally agreed tax standard'. ${ }^{35}$ Recent comments from OECD officials have indicated, though, that the criteria could be tightened in the future. ${ }^{36}$ Another problem is that, despite the OECD standards, the real ownership of certain financial vehicles in tax havens can still be concealed, which causes considerable leakage (Ref. 31, p. 61).

Above, we pointed out that new constitutionalism as the institutional pillar of neo-liberal globalisation provides the latter with resilience. This can be illustrated with the example of tax policy as well. First of all, the financial crisis has not put into question globalisation itself, more precisely the current level of free movement of capital, goods and services. Governments have not announced to collectively roll-back globalisation by reinstalling capital controls or huge trade and investment barriers. Note that a real Tobin tax, as James Tobin himself proposed it - i.e. a tax of about $0.1 \%$ or more on international currency transactions as a means to discourage international financial speculation and preventively stabilise financial markets - would have the effect of slowing down international capital movements and thus contributing to 'de-globalisation'. But the kind of financial transaction taxes that are now on the table are of a completely different type. First, the rate would be much lower, so that financial markets would only be lightly affected $(0.005 \%$ is an often cited rate - Ref. 25$)$. Second, in most proposals the purpose of the tax would not be to slow down international financial transactions, but mainly to finance the costs of the financial crisis, development or climate policies. 
Third, under some of the most important proposals, various financial transactions would be targeted (including sale of shares), and not only cross-border movements.

In the absence of de-globalisation proposals, the only way to compensate the political-geographical mismatch between financial and economic mobility on the one hand and political regulation on the other, is to introduce global forms of regulation that create a level playing field. As we have seen, this is basically the path politicians have attempted to follow over the last few years. Free movement within an integrated economic space has remained more or less intact, but governments have tried to build international frameworks in which the 'race to the bottom' of effective tax rates is stopped (e.g., EU and OECD codes of conducts against special tax schemes for corporations) or national policies can be enforced extraterritorially (e.g., EU and OECD standards with regard to exchange of information). But at the same time, we see that these frameworks are relatively weak. This kind of 'horizontal' regulation faces tremendous collective action problems. A number of jurisdictions do not want to strengthen international tax cooperation, and can to some extent determine the pace of international decision-making and even block certain efforts. For example, the US is still opposed to a global transaction tax, while the proponents are lukewarm to introduce it unilaterally. The EU savings directive still contains several loopholes (a series of financial products and vehicles are exempted), but countries such as the UK and Luxembourg are reluctant to expand its scope. Their positions are crucial, since in the EU, as a feature of today's new constitutionalism, unanimity voting applies for all tax matters. The deepening of multipolarity and the evolution to a 'post-Western' world are not a blessing either in this respect. Russia and some Gulf states display features of a tax haven and are not renowned for strict financial regulation. China has been reported to protect tax havens like Hong Kong and Macau during G20 negotiations (Ref. 37). The new constitutionalist context continues to enable the authorities of certain jurisdictions, aligned with particular material interests, to act as de facto veto players.

\section{Conclusion}

To summarise, the crisis has to some extent shaken the foundations of neo-liberal hegemony, in particular at the ideational level. But it is absolutely premature to announce the end of neo-liberal globalisation. Neo-liberal hegemony has only partially been de-legitimised. The free movement of capital and goods remains untouched. One of the reasons is that neo-liberalism itself and the ensuing weakness of financial regulation have been blamed for the subprime crisis, but not financial and economic globalisation as such, which in its current form is equally a product of neo-liberalism. This state of affairs allows the politicalgeographical mismatch between private economic activity and public regulation 
to persist. Economic and new constitutionalist, legal anchoring of neo-liberal globalisation remain in place, while global, horizontal regulation directed at a level playing field is severely hampered by collective action problems, in favour of certain material interests at the core of neo-liberal hegemony.

\section{References}

1. S. Gill (2008) Power and Resistance in the New World Order. 2nd Edition, Fully Revised and Updated (Houndmills Basingstoke: Palgrave Macmillan).

2. P. G. Cerny (1997) The paradoxes of the competition state: the dynamics of political globalization. Government \& Opposition, 32, pp. 251-274.

3. R. O. Keohane (1984) After Hegemony: Cooperation and Discord in the World Political Economy (Princeton, NJ: Princeton University Press).

4. R. O. Keohane and J. S. Nye (2000) Globalization: what's new? What's not? (And so what?) Foreign Policy, 104-119.

5. E. Swyngedouw (2004) Globalisation or 'glocalisation'? Networks territories and rescaling. Cambridge Review of International Affairs, 17, pp. 25-48.

6. S. Gill and D. Law (1989) Global hegemony and the structural power of capital. International Studies Quarterly, 33, pp. 475-499.

7. C. Devos (1999) The myth of globalisation and its strategic consequences, Demokritos. Mededelingen van de Vakgroep Politieke Wetenschappen. Universiteit Gent.

8. T. Fougner (2006) The state, international competitiveness and neoliberal globalization: is there a future beyond the competition state? Review of International Studies, 32, pp. 165-185.

9. R. Schmidt (2001) Efficient capital controls. Journal of Economic Studies, 28, pp. 199-212.

10. E. Helleiner and S. Pagliari (2009) Towards a new Bretton Woods? The first G20 leaders summit and the regulation of global finance. New Political Economy, 14, pp. 275-287.

11. See http://www.g20.org/Documents/final-communique.pdf, §23.

12. Nevertheless, the crisis could never have occurred without free capital mobility. As noted by H. Dieter, L. Seabrookeand E. Tsingou (2009) The Global Credit Crisis and the Politics of Financial Reform. GARNET Policy Brief No. 8. 'A key aspect of the current crisis is that the US was able to draw on the savings of Asia and continental Europe, drowning itself in a sea of foreign liquidity. Restrictions on capital flows would have prevented the US crisis and subsequent global contagion as the US would have had to finance its spending exuberance from domestic savings - since that would not have been possible, the bubble would not have inflated as much as it has. In their various formats (restrictions, taxes, reserve requirements) capital controls might therefore have been a legitimate tool of economic policy.'

13. B. Thirkell-White (2009) Dealing with the banks: populism and the public interest in the global financial crisis. International Affairs, 85, pp. 689-711.

14. A. Baker (2009) Deliberative equality and the transgovernmental politics of the global financial architecture. Global Governance, 15, pp. 195-218. 
15. T. Porter (2009) Why international institutions matter in the global credit crisis. Global Governance, 15, pp. 3-9.

16. E. Tsingou (2010) Regulatory reactions to the credit crisis: analysing a policy community under stress. In: E. Helleiner, S. Pagliari and H. Zimmermann (eds) Global Finance in Crisis: The Politics of International Regulatory Change (London: Routledge).

17. N. R. Lardy (2002) Integrating China into the Global Economy (Washington, DC: Brookings Institution Press).

18. C. Alden and M. A. Vieira (2005) The new diplomacy of the South: South Africa, Brazil, India and trilateralism. Third World Quarterly, 26, pp. 1077-1095.

19. Although China (eventually supported by the other BRICs) has criticised the inefficiencies associated with the global dollar standard and is increasingly trying to promote the international use of its currency, financial liberalisation will be a necessary condition for its currency to acquire global currency status (B. Eichengreen (2009) The dollar dilemma. Foreign Affairs, 88). In this way, China's contestation of one of the main pillars of US hegemony may lead it to embrace one of the main pillars of neoliberal hegemony - free capital mobility.

20. M. Mah-Hui Lim (2008) Old Wine in a New Bottle: The Subprime Mortgage Crisis - Causes and Consequences. Working Paper No. 532 (New York: Levy Economics Institute).

21. N. Cori (2008) L'Europe sonne la réouverture de la chasse au paradis fiscal, Libération, 22 October. http://www.liberation.fr/economie/0101163945-1europe-sonne-la-reouverture-de-la-chasse-au-paradis-fiscal.

22. D. Lesage (2008) Global taxation governance after the 2002 UN Monterrey conference. Oxford Development Studies, 36, pp. 281-294.

23. L. Elliott (2009) IMF chief backs down on Tobin tax. The Guardian, 23 November. http://www.guardian.co.uk/business/2009/nov/23/cbiglobal-economy.

24. J. Treanor (2009) Tobin tax gains supporters in the City as lord mayor criticises bonus culture. The Guardian 16 November. http:// www.guardian.co.uk/business/2009/nov/16/tobin-tax-gains-city-support.

25. N. Mathiason and J. Treanor (2009) Gordon Brown in secret push to sell 'Tobin tax' to City. The Guardian, 9 November. http:// www.guardian.co.uk/business/2009/nov/09/tobin-tax-gordon-brown-city.

26. I. Traynor and A. Clark (2009) France and Germany back UK bonus tax. The Guardian, 10 December 2009. http://www.guardian.co.uk/business/ 2009/dec/10/france-germany-back-uk-bonus-tax.

27. N. Pratley (2009) Banks face insurance levy and a tax on financial transactions. The Guardian, 8 December 2009. http://www.guardian.co.uk/ business/2009/dec/08/tobin-tax-banking.

28. D. Lesage, D. McNair and M. Vermeiren (2010) From Monterrey to Doha: taxation and Financing for Development. Development Policy Review, 28, pp. $155-172$.

29. A. Gurría (2008) The global tax dodgers. The Guardian, 27 November.

30. N. Mathiason (2009) New threat for UK's offshore havens: tax. The Guardian, 28 October. http://www.guardian.co.uk/business/2009/oct/28/ tax-more-tax-havens-told. 
31. M. Foot (2009) Final Report of the independent Review of British offshore financial centres (London: Crown).

32. (Anon.) (2009) Les banques françaises vont quitter les paradis fiscaux, c'est promis, Libération. 1 October. http://www.liberation.fr/economie/ 0101594500-les-banques-francaises-vont-quitter-les-paradis-fiscaux.

33. See http://levin.senate.gov/newsroom/supporting/2009/ PSI.StopTaxHavenAbuseAct.030209.pdf.

34. N. Mathiason (2009) US tax investigators win fight to force UBS to disclose accounts worth \$18bn. The Guardian, 19 August. http:// www.guardian.co.uk/business/2009/aug/19/tax-avoidance-ubs-us-economy.

35. OECD (2009) Countering Offshore Tax Evasion. Some Questions and Answers on the Project (Paris: OECD).

36. See http://taxjustice.blogspot.com/2009/12/oecd-to-tighten-tax-havencriteria.html.

37. A. Faiola and M. Jordan (2009) Tax-Haven blacklist stirs nations. The Washington Post, 4 April. http:/www.washingtonpost.com/wp-dyn/ content/article/2009/04/03/AR2009040303394.html.

Dries Lesage is lecturer at the Ghent Institute for International Studies (Ghent University, Belgium). He teaches 'Theories of International Relations' and 'Globalisation and Global Governance'. His research interests are global governance in general, the G8 and G20, global taxation governance and global energy governance.

Mattias Vermeiren is a researcher at the Ghent Institute for International Studies (Ghent University, Belgium), where he is conducting a $\mathrm{PhD}$ study on the political economy of the global imbalances and the transition from a hegemonic monetary system towards an increasingly multipolar system. 